\section{ST

Electrochemical Technology

Program

Electrochemical Technology

Program

Electrochemical Technology

Program

Electrochemical Technology

Program

Electrochemical Technology

Program

Electrochemical Technology

Program

Electrochemical Technology

Program

Electrochemical Technology

Program

Electrochemical Technology

Program

Electrochemical Technology

Program

Electrochemical Technology

Program

Electrochemical Technology

Program

Electrochemical Technology

Program

Electrochemical Technology

Program

Electrochemical Technology

Program

Electrochemical Technology

Program

Electrochemical Technology

Program
ANL-89/26

\section{Electroformation of Uranium Hemispherical Shells}

by S. L. Marshall, L. Redey,

G. F. Vandegrift, and D. R. Vissers
DO NOI BAGROFILI

COVER

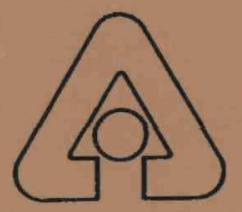

Argonne National Laboratory, Argonne, Illinois 60439

operated by The University of Chicago

for the United States Department of Energy

Chemical Technology

Division

Chemical Technology

Division

Chemical Technology

Division

Chemical Technology

Division 
Argonne National Laboratory, with facilities in the states of Illinois and Idaho, is owned by the United States government, and operated by The University of Chicago under the provisions of a contract with the Department of Energy.

\section{DISCLAIMER}

This report was prepared as an account of work sponsored by an agency of the United States Government. Neither the United States Government nor any agency thereof, nor any of their employees, makes any warranty, express or implied, or assumes any legal liability or responsibility for the accuracy, completeness, or usefulness of any information, apparatus, product, or process disclosed, or represents that its use would not infringe privately owned rights. Reference herein to any specific commercial product, process, or service by trade name, trademark, manufacturer, or otherwise, does not necessarily constitute or imply its endorsement, recommendation, or favoring by the United States Government or any agency thereof. The views and opinions of authors expressed herein do not necessarily state or reflect those of the United States Government or any agency thereof.

\section{DO NOT MICROFILM THIS PAGE}

This report has been reproduced from the best available copy.

Available from the

National Technical Information Service

U.S. Department of Commerce

5285 Port Royal Road

Springfield, VA 22161

Price: Printed Copy A03

Microfiche A01 


\section{DISCLAIMER}

This report was prepared as an account of work sponsored by an agency of the United States Government. Neither the United States Government nor any agency Thereof, nor any of their employees, makes any warranty, express or implied, or assumes any legal liability or responsibility for the accuracy, completeness, or usefulness of any information, apparatus, product, or process disclosed, or represents that its use would not infringe privately owned rights. Reference herein to any specific commercial product, process, or service by trade name, trademark, manufacturer, or otherwise does not necessarily constitute or imply its endorsement, recommendation, or favoring by the United States Government or any agency thereof. The views and opinions of authors expressed herein do not necessarily state or reflect those of the United States Government or any agency thereof. 


\section{DISCLAIMER}

Portions of this document may be illegible in electronic image products. Images are produced from the best available original document. 
Distribution Category:

Materials (UC-504)

ANL $-89 / 26$

DE90 004489

ANL $-89 / 26$

ARGONNE NATIONAL LABORATORY

9700 South Cass Avenue

Argonne, Illinois 60439

\section{ELECTROFORMATION OF URANIUL \\ WHISTP IERICAL SHELLS}

by

S. L. Marsha11, L. Redey, G. F. Vandegrift, and D. R. Vissers

Chemical Technology Division

November 1989

\section{DISCLAIMER}

This report was prepared as an account of work sponsored by an agency of the United States Government. Neither the United States Government nor any agency thereof, nor any of their employees, makes any warranty, express or implied, or assumes any legal liability or responsibility for the accuracy, completeness, or usefulness of any information, apparatus, product, or process disclosed, or represents that its use would not infringe privately owned rights. Refer ence herein to any specific commercial product, process, or service by trade name, trademark, manufacturer, or otherwise does not necessarily constitute or imply its endorsement, recommendation, of favoring by the United States Government or any agency thereof. The views and opinions of authors expressed herein do not necessarily state or reflect those of the United States Government or any arencv thereaf

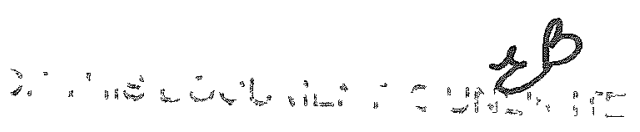



ABSTRACT $\ldots \ldots \ldots \ldots \ldots \ldots \ldots \ldots \ldots \ldots \ldots \ldots \ldots \ldots \ldots \ldots \ldots \ldots \ldots$

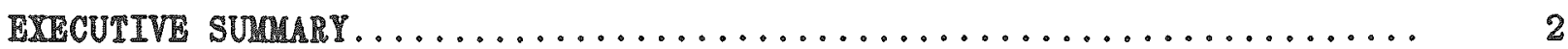

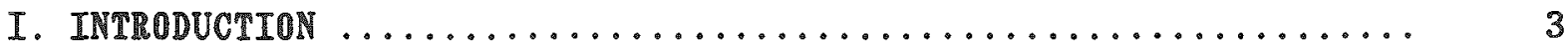

II. BACKGROUND $\ldots \ldots \ldots \ldots \ldots \ldots \ldots \ldots \ldots \ldots \ldots \ldots \ldots \ldots \ldots \ldots$

III. EXPERIMENTAL $\ldots \ldots \ldots \ldots \ldots \ldots \ldots \ldots \ldots \ldots \ldots \ldots \ldots \ldots \ldots \ldots$

A. Cel1 Assembly ............................ 5

B. Tubular Cathode Plating Assembly.................. 6

C. Instrumentation.......................... 7

IV. RESUTS AND DISCUSSION........................ 8

A. Potentia1-Step Current Transients ................... 8

B. Application of Pulsed Potential................... 9

C. Coulombic Efficiency........................... 13

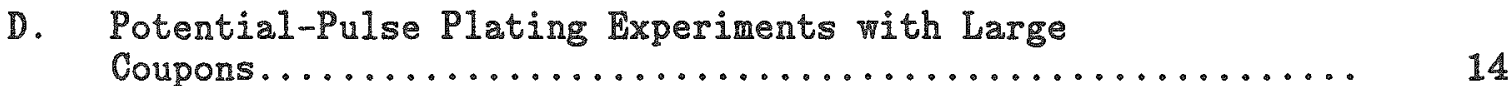

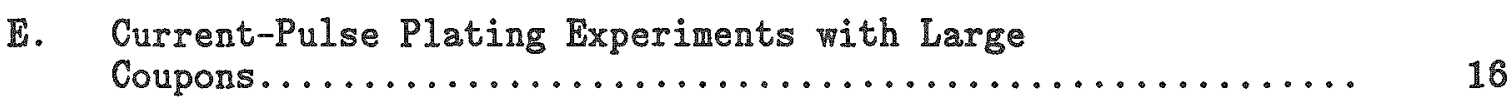

F. Tubular Cathode Plating Experiment................ 17

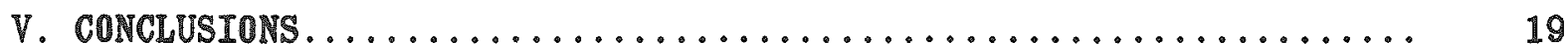

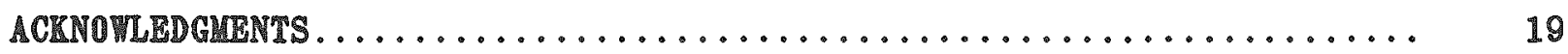

REPREENCES $\ldots \ldots \ldots \ldots \ldots \ldots \ldots \ldots \ldots \ldots \ldots \ldots \ldots \ldots \ldots \ldots \ldots \ldots \ldots \ldots \ldots$ 


\section{LIST OF FIGURS}

No.

Title

$\underline{\text { Page }}$

1. Diagram of Cell Assembly........................ 6

2. Photograph Showing Ce11 Components and Assembled Ce11 ....... 7

3. Current Transients Resulting from Potential Steps from $V_{1}$

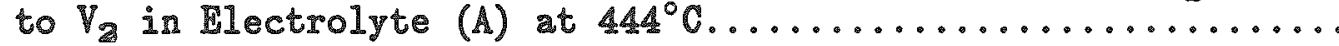

4. Pulsed Applied Potential Signal and Transient Current Response of Nickel Test Electrode in Electrolyte (C) at $558^{\circ} \mathrm{C} \ldots . . . . .$.

5. Predicted Relation between Potential-Pulse Plating Parameters Corresponding to the Absence of Dendrites..................

6. Boundaries of Dendrite-Free $V_{2}-r$ Regions for Electrolyte (B) at $509^{\circ} \mathrm{C}$, Electrolyte (C) at $455^{\circ} \mathrm{C}$, Electrolyte (C) at $504^{\circ} \mathrm{C}$, and Electrolyte (C) at $550^{\circ} \mathrm{C}$

7. Coulombic Efficiency for Potential-Pulse Plating as Function of $V_{2}$ and $r$ in electrolyte $(B)$ at $509^{\circ} \mathrm{C} \ldots \ldots \ldots \ldots \ldots$

8. Potential-Pulse Plated Uranium Deposit on Nickel Coupon

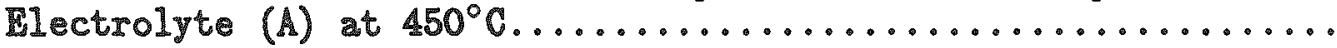

8. Bipolar Current-Pulse Plated Uranium Deposit on Nickel

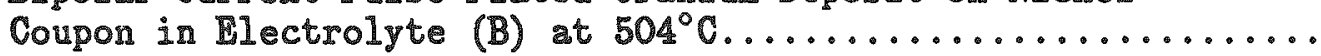

10. Bipolar Current-Pulse Plated Uranium Deposit on Nickel

Tubular Cathode. 


\title{
ELECTROFORMATION OF URANIUM
}

HEUTSPHERICAL SHBLLS

by

S. L. Marsha11, L. Redey, G. F. Vandegrift, and D. R. Vissers

\begin{abstract}
This effort was directed at developing an electrochemical process for forming uniform and dendrite-free deposits of uranium from molten salts. This process is to be used for the electroformation of free-standing hemispherical shells of uranium for nuclear applications. Electrodeposition of uranium onto a substrate was accomplished with a fused chloride mixture containing 42 wt $\%$ $\mathrm{UCl}_{3}$ and a fused chloride-fluoride mixture containing 4 it $\% \mathrm{UF}_{4}$. Under pulsed potential control at $504^{\circ} \mathrm{C}$, the chloride-fluoride mixture yielded the widest range of plating conditions for which dendrites could be avoided. Bipolar current pulse plating with both electrolytes gave good results, and successful application of this technique to a large tubular cathode has been demonstrated.
\end{abstract}




\section{EIECUTIV SUMAAI}

The objective of this effort was to develop the base technology required for the electroformation of free-standing hemispherical shells of uranium for nuclear applications. To meet this objective, we focused our work on the development of an electrochemical process for forming uniform and dendritefree deposits of uranium from molten salt. The primary problem in the process is that the reversible deposition kinetics of uranium results in a strong tendency toward formation of dendritic (irregular, tree-like) deposits. Consequently, our efforts have been focused on developing plating processes that permit preparation of dendrite-free deposits.

We initially determined conditions for pulse potential electrodeposition of uranium from a molten salt mixture (A) consisting of 20 wt $\% \mathrm{UCl}_{3}$ in $\mathrm{LiCl}-\mathrm{KCl}$ eutectic onto various metal substrates ( $\mathrm{Ta}, \mathrm{Ni}, \mathrm{Al}, \mathrm{Fe}, \mathrm{Cu}$, and stainless steel). Next, we determined the dendrite-free plating conditions on nickel using both the potential-pulse and the bipolar current-pulse techniques in two more electrolytes, which had the compositions (in wt \%): (B) $42.1 \mathrm{UCl}_{3}-13.5 \mathrm{LiCl}-44.4 \mathrm{KCl}$ and (C) $4.5 \mathrm{UF}_{4}$ in $43.3 \mathrm{LiCl}-55.1 \mathrm{KCl}-1.6 \mathrm{LiF}$.

The results of these studies indicated that near-dendrite-iree coatings can be prepared by using either the potential-pulse or bipolar current-pulse plating regimes. Plating rates of nearly 1 mil/h were achieved with both plating techniques. The potential-pulse plating regime for dendrite-free deposits had the widest range of operating parameters with electrolyte (C), while the bipolar current-pulse regime appears to give excellent results in both electrolytes (B) and (C) [electrolyte (A) was not evaluated with this plating regime].

Because a bipolar current-pulse technique requires only simple, inexpensive galvanostats with polarity reversal capabilities rather than the expensive potentiostat and a stable reference electrode required by the potential-pulse technique, it seens appropriate that future effort should focus on the former technique and be expanded to the all-fluoride-ion electrolyte systems using either nickel or uranium plating surfaces. 


\section{INTRODUCTION}

The objective of this research effort was to develop the base technology required for electrochemical formation of thick, metallurgically sound uranium bodies of specified geometries with acceptable mechanical properties for nuclear applications. The effort was directed primarily toward determining how the electrolyte composition and plating regime affected the quality of the uranium plate formed on substrate material.

The plating regimes evaluated in this effort were the potential-pulse technique, developed last year, and the bipolar current-pulse technique. The latter utilizes a very short cathodic current pulse to deposit a monolayer or so of uranium followed by an anodic current pulse to dissolve the major part of that which was plated. The thought here was that any irregularities in the deposit would be removed during the anodic pulse, and thus, irregularities and/or dendrite formation in the uranium coatings would be avoided.

The compositions of the electrolyte mixtures (in wt \%) investigated were as follows: electrolyte (A), $20 \mathrm{UCl}_{3}$ in $\mathrm{LiCl}-\mathrm{KCl}$ eutectic; electrolyte (B), $42.1 \mathrm{UCl}_{3}-13.5 \mathrm{LiCl}-44.4 \mathrm{KCl}$; and electrolyte $(\mathrm{C}), 4.5 \mathrm{UF}_{4}$ in $43.3 \mathrm{LiCl}-55.1$ KC1-1.6 LiF eutectic mixture. The objective of this study was (1) to determine how the higher level of uranium trichloride in the chloride-ion molten salts affected the deposits relative to the $20 \mathrm{wt} \% \mathrm{UCl}_{3}$ in $\mathrm{LiCl}-\mathrm{KCl}$ eutectic and (2) to determine whether good coatings could be prepared from melts containing both the chloride and fluoride ions. In the latter case, we felt that we might be able to develop a bath which is similar in plating properties to the all-fluoride-ion bath but which would not require the high plating temperature and the difficult electrolyte purification regime of the all-fluoride-ion bath. 


\section{BACKGROUND}

The electrochemistry of uranium in fused salts has been of technological importance since the early days of the nuclear industry. Preparation of uranium powder by electrolysis was first described by Driggs and Lilliendah1. ${ }^{1}$ Electrolytic preparation was also performed during the Manhattan Project ${ }^{2}$ and subsequently adapted to the refinement of uranium produced by nonelectrochemical methods ${ }^{3}$ and nuclear fuel reprocessing. "While several potentiometric studies of $U / U^{3+}$ (Refs. 5-7) and $U^{3+} / U^{4+}$ (Refs. 8 and 9) half-cells have appeared, relatively little attention has been devoted to the kinetics of these reactions. The first application of transient techniques was described by Caligara et al. ${ }^{10}$ who used chronopotentiometry to investigate the kinetics of oxidation of $\mathrm{U}^{3+}$ to $\mathrm{U}^{4+}$. Very recently, cyclic voltametry experiments were conducted by Poa et al. ${ }^{11}$ on the reduction of $\mathrm{UCl}_{3}$ to $\mathrm{U}$ in a molten $\mathrm{LiCl}-$ $\mathrm{NaCl}-\mathrm{CaCl}_{2}-\mathrm{BaCl}_{2}$ mixture. In this paper, we describe aspects of the transient behavior of uranium electrodeposition that are relevant to the development and application of pulse-plating techniques.

Since the uranium objects for applications require high standards of surface uniformity, the most important problem to be addressed was that of avoiding the well-known tendency of uranium to form dendritic ${ }^{12}$ or powdery 1,2 deposits. Broc ${ }^{12}$ has reported that smooth uranium coatings about 4 mil $(100 \mu \mathrm{m})$ in thickness can be electrodeposited from molten fluoride mixtures (UF $3 \mathrm{UF}_{4}$ in FLINAK). This work required high operating temperatures (about $800^{\circ} \mathrm{C}$ ) and extensive purification of the fluoride electrolyte materials. We chose instead to work with the $\mathrm{LiCl}-\mathrm{KCl}-\mathrm{UCl}_{3}$ and the $\mathrm{LiCl}-\mathrm{KCl}-\mathrm{LiF}-\mathrm{UF}_{3}$ systems at temperatures between $440^{\circ} \mathrm{C}$ and $560^{\circ} \mathrm{C}$.

In view of the importance of dendrite formation in relation to metal electrodeposition in general and to our work in particular, some introductory remarks are in order on what constitutes a dendrite. Electrodeposition of metals is well known to result in a wide variety of structures, from essentially smooth surfaces to highly branched crystals. The term "dendrite," usually applied to the latter extreme, literally suggests a tree-like structure, but within this general category various forms are possible. These have been described by Wranglen ${ }^{13}$ and rationalized by him on the basis of the crystal structure of the various metals concerned. More recently, dendritic electrodeposits have been described as fractal structures, characterized by a fractional dimensionality. ${ }^{14}$

Unfortunately, there is no term in common use that satisfactorily describes metallic deposits lying between the above two extremes, in which the crystals are obviously discrete but are not highly branched and do not possess the scale-invariance characteristic of a fractal structure. An obvious common characteristic of the dendrites described in Wranglén's paper ${ }^{13}$ is their elongation. This observation suggests that elongation of crystals may be identified as a tendency toward dendritic growth. Several theoretical treatments $^{15}$ of dendritic electrodeposition are also based on this concept. Although elongated crystals are not necessarily dendritic, in the present report we apply the term "dendrite" to crystals in which the height is noticeably greater than the diameter. 


\section{BIPERIMENTAL}

\section{A. Cell Assembly}

Molten alkali halide salts, in general, are characterized by an extreme sensitivity to moisture. Solutions of uranium salts in alkali halide melts also exhibit a pronounced reactivity toward oxygen. Reaction with oxygen and water vapor leads to formation of oxychlorides, the presence of which has been shown to lower the quality of electrodeposited specimens.2,12 For this reason, the experiments were carried out in a glove box (Vacuun Atmospheres Corporation) under purified helium, with the oxygen and moisture content maintained below 1 ppm.

The electrolytes used in this work were as follows.

Electrolyte (A). A 20 wt \% solution of $\mathrm{UCl}_{3}$ was prepared by reaction of excess uranium metal with a solution of $\mathrm{CdCl}_{2}$ in molten LiCl-KCI eutectic at $450^{\circ} \mathrm{C}$. The reaction proceeded according to the equation:

$$
2 \mathrm{U}+3 \mathrm{CdCl}_{2}=2 \mathrm{UCl}_{3}+3 \mathrm{Cd}
$$

This reaction has been used extensively in experiments conducted in this laboratory in connection with the Integral Fast Reactor program ${ }^{11}$ and is known to be quantitative.

Electrolyte (B). A ternary eutectic with composition 12.0 mol \% (42.4 wt \%) UCI, $29.5 \mathrm{~mol} \%(12.8 \mathrm{wt} \%) \mathrm{LiCl}$, and $58.5 \mathrm{~mol} \%$ (44.8 wt \%) $\mathrm{KCl}$ was prepared by melting together $182.80 \mathrm{~g} \mathrm{FeCl}_{2}$ (Anderson Physics Laboratory), $221.75 \mathrm{~g} \mathrm{KC1}$ (Alpha), and $227.76 \mathrm{~g}$ LiCl-KCl eutectic (Anderson Physics Laboratory) and allowing this mixture to react with $228.78 \mathrm{~g}$ uranium metal. This resulted in the formation of $\mathrm{UCl}_{3}$ according to the equation:

$$
2 \mathrm{U}+3 \mathrm{FeCl}_{2}=2 \mathrm{UCl}_{3}+3 \mathrm{Fe}
$$

Thermodynamic data suggest that this reaction is quantitative. The literature value ${ }^{18}$ of $335^{\circ} \mathrm{C}$ for the melting point of this eutectic was verified by measurement of a cooling curve, but cooling of the molten electrolyte from $500^{\circ} \mathrm{C}$ to $450^{\circ} \mathrm{C}$ resulted in precipitation of solids to the extent that insufficient liquid remained for the experiments. To lower the liquidus temperature, a further $6.4 \mathrm{~g} \mathrm{LiCl}$ was added, resulting in a final electrolyte composition only slightly different from that of the ternary eutectic: 11.8 mol \% (42.1 wt \%) UC1 $3,30.8$ mol \% (13.5 wt \%) LiCl, and 57.4 mol \% (44.4 wt \%) $\mathrm{KCl}$.

Electrolyte (C). A solution of $U^{3+}$ was prepared by reaction of excess uranium metal with a 4.5 wt \% solution of UF 4 (supplied by the $Y-12$ Plant of Oak Ridge National Laboratory) in a ternary eutectic with composition 56.0 mol \% (43.3 wt \%) LiCl, $40.5 \mathrm{~mol} \%$ (55.1 wt \%) KCl, and 3.5 mol \% (1.6 wt \%) LiF. Trivalent uranium was formed by the reaction ${ }^{12}$ :

$$
3 U^{4+}+U=4 U^{3+}
$$


The anodes used in the experiments were rods or discs of pure uranium meta1, with stainless steel rods serving as current collectors.

In exploratory electrodeposition experiments, the cathode consisted of a disc $\left(0.178 \mathrm{~cm}^{2}\right.$ area) made from a $3 / 16-i n .(0.48 \mathrm{~cm})$ dia nickel rod with an insulating sheath of boron nitride covering the cylindrical surface. Largerscale plating experiments used cylindrical nickel coupons of $7.74 \mathrm{~cm}^{2}$ total area. Coupons of copper, tantalum, and aluminum mere also tested.

The reference electrode consisted of a 3/8-in. $(0.95 \mathrm{~cm})$ dia uranium metal rod. The potentials in this report are quoted with respect to the uranium electrode in the same electrolyte as the cathode. Changing the position of the reference electrode relative to the working electrode was observed not to exert a significant effect on the observed current. This indicates that uncompensated solution resistance effects are negligible.

The temperature of the electrolyte was monitored with a Chromel-Alumel thermocouple and maintained thermostatically to $\pm 1^{\circ} \mathrm{C}$.

A diagram of the cell assembly is shown in Fig. 1.

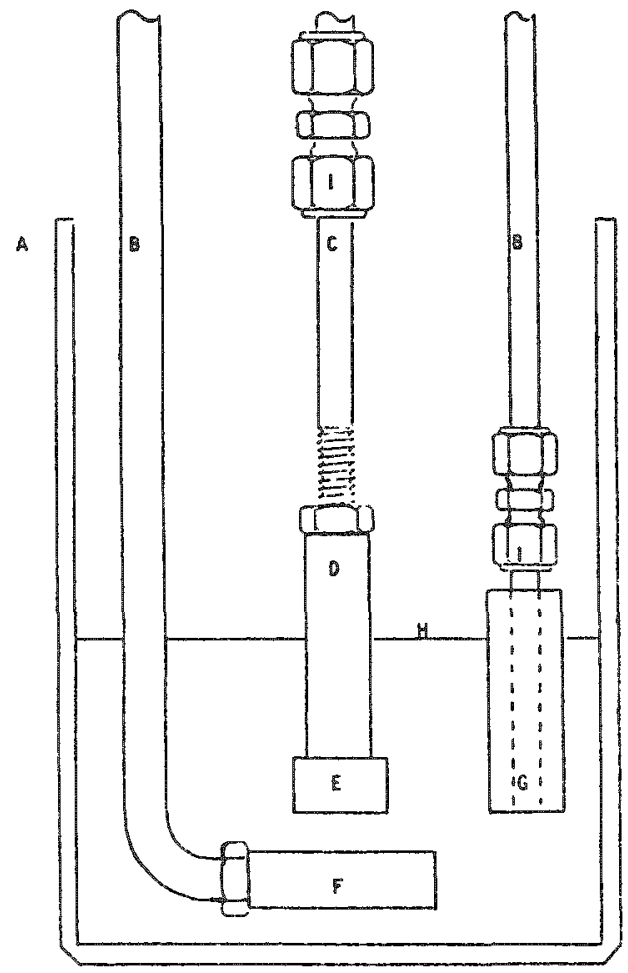

Fig. 1 .

Diagram of Cell Assembly. A: mild steel crucible; B: stainless steel support rods/electrode leads; $\mathrm{C}$ : threaded stainless steel stud for cathode; D: alumina tube insulator; $\mathbb{E}$ : cathode coupon; $\mathrm{F}$ : uranium disk anode; $G$ : uranium rod reference electrode surrounded by boron nitride insulator; $\mathrm{H}$ : electrolyte level; I: tube-tube couplings (Parker-CPI).

\section{B. Tubular Cathode Plating Assembly}

To demonstrate the feasibility of electrodepositing uranium on the inner surface of a large tube, a special two-electrode cell was developed. Electrolyte (B) was contained in a 1-1/2 in. (4 cm) ID alumina crucible surrounded by a stainless steel secondary crucible. The cathode (101 $\mathrm{cm}^{2}$ area) was made 
from a 5 in. $(12.70 \mathrm{~cm})$ length of nickel tubing, 1 in. $(2.54 \mathrm{~cm})$ ID and $1-1 / 4$ in. $(3.18 \mathrm{~cm})$ OD, with opposing external grooves cut in the wall to facilitate separation of the tube into halves after the experiment for examination of the electrodeposit. Nickel tubing, $1 / 8 \mathrm{in.}(0.32 \mathrm{~cm})$ ID and $1 / 4 \mathrm{in} .(0.64 \mathrm{~cm}) \mathrm{OD}$, welded to the upper rim of the cathode, served as the current collector and thermocouple gland.

A $5 / 16$ in. $(0.79 \mathrm{~cm})$ dia uranium rod was positioned coaxially with the cathode by use of a boron nitride insulator with center hole, lying on the bottom of the alumina crucible. The entire assembly, with the heat reflectors for the furnace vell, is shown in Fig. 2.

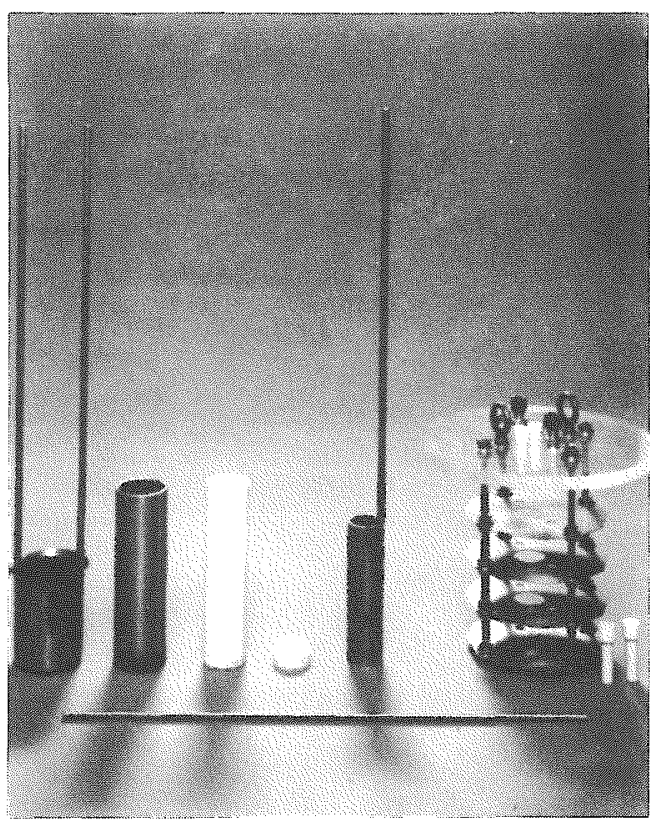

(a)

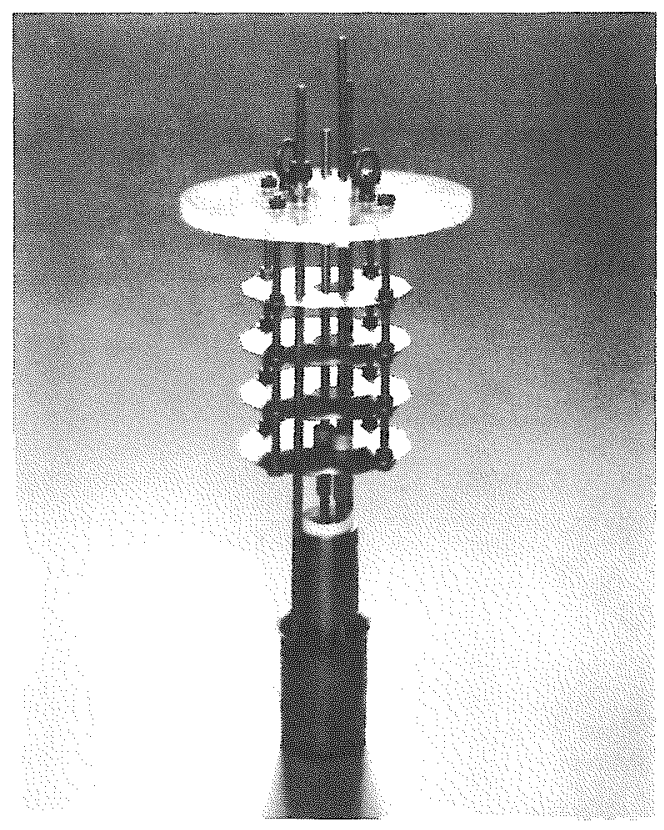

(b)

Fig. 2. Photograph Showing Cell Components (a) and Assembled Ce11 (b). The cell components in Fig. 2a are, from left to right: cell hanger, steel crucible, $\mathrm{Al}_{2} \mathrm{O}_{3}$ crucible, $\mathrm{BN}$ insulator, $\mathrm{Ni}$ tube cathode, heat shield assembly, $\mathrm{Al}_{2} 0_{3}$ insulator sleeves, and a 5/16-in. dia rod in front of the other components.

\section{Instrumentation}

Electrical control of the cell was provided by a potentiostat (Princeton Applied Research, model 173) fitted with a digital coulometer (Princeton Applied Research, model 179) and an electronic function generator (Princeton Applied Research, model 175). In the experiments with the large coupons, application of nucleation pulses and preanodization of the substrate electrodes was effected by switching control of the cell from the potentiostat to a 25 A constant-current power supply (Sorensen, model SRL 20-25). For plating experiments with the tubular cathode, a reverse-pulse plating machine (Dynatronix, model DPR 20-100-400) was used. 


\section{RESULTS AND DISCUSSION}

\section{A. Potentia1-Step Current Transients}

Potentiostatic transient experiments were performed to examine the relaxation behavior of the current as a function of time at constant potential and to determine the steady-state polariaation curve. Information of both kinds was of interest to us in the design of electroplating experiments.

Potential-step transients for electrodeposition of uranium from electrolyte (A), onto a nickel disc electrode of $0.178 \mathrm{~cm}^{2}$ area, are characterized by maxima in the current which occur progressively earlier as the deposition potential $\mathrm{V}_{2}$ becomes progressively more negative (see Fig. 3 ).

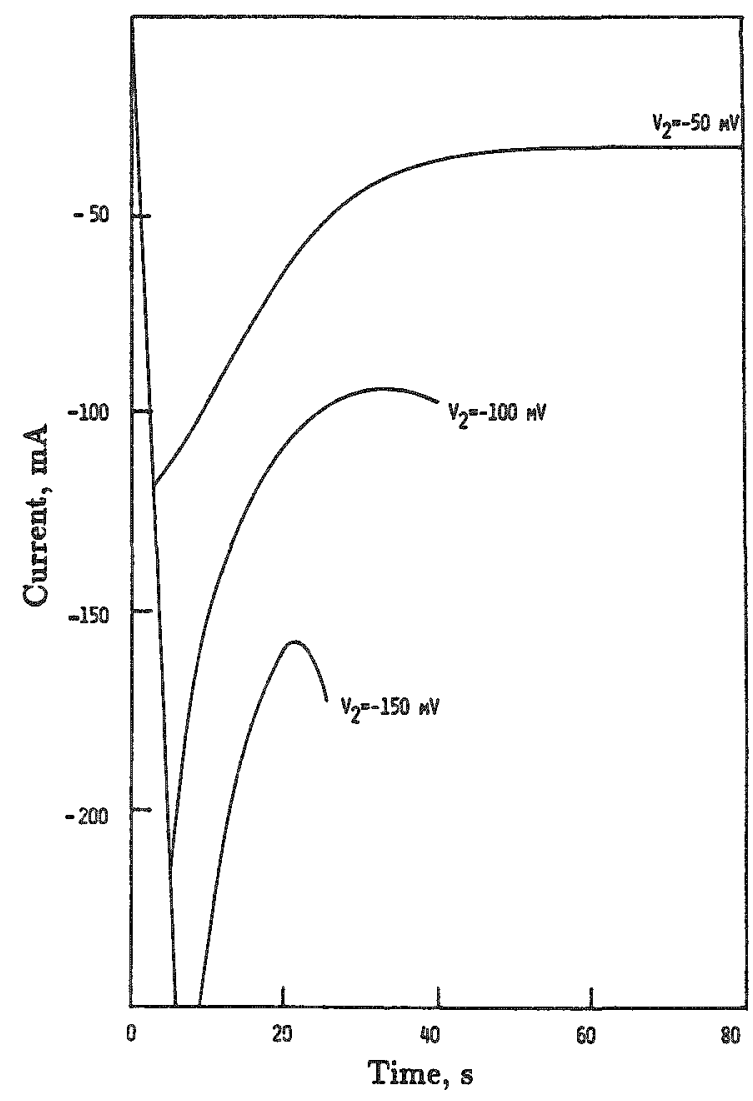

Fig. 3.

Current Transients Resulting from Potential Steps from $V_{1}$ to $V_{2}$ in Electrolyte (A) at $444^{\circ} \mathrm{C}$. $V_{1}=300 \mathrm{mV}$.

Such maxima were observed to correspond to the formation of dendrites, and similar results mere obtained in experiments in different electrolytes. The most reasonable explanation for these current maxima is that they result from the enlargement of the electrode surface area associated with dendrite formation. This is consistent with the strong tendency of uranium to form dendrites, as already reported in the literature. $2,4,12,17$

The construction of an empirical representation of the electrodeposition current as a function of time is difficult, since the transient currents to not obey the exponential or inverse power decay laws usually associated 
with the potential-step technique. Construction of a steady-state current/ potential curve is also difficult, since limiting steady values of the current are not reached. Although the usual steady-state kinetic method is evidently not strictly applicable, a crude polarization curve may be constructed by considering the maximum current attained before surface enlargement effects start to predominate. The variation of these maximum currents (I) with the deposition potentials (V) is empirically represented by the equation

$$
I=I_{0}\left[\exp \left(a_{2} F\left(V-V_{x}\right) / R T\right)-\exp \left(-a_{c} F\left(V-V_{x}\right) / R T\right)\right]
$$

The quantities $V_{r}, I_{0}, a_{a}$, and $a_{c}$ represent the apparent values of the reversible potential, exchange current, anodic transfer coefficient, and cathodic transfer coefficient, respectively. Least-squares curve fitting yields $i_{0}=I_{0} \times 5.61 \mathrm{~cm}^{-2}=240 \mathrm{~mA} \mathrm{~cm}-2, V_{x}=10 \mathrm{mV}, a_{a}=0.590$, and $a_{c}=$ 1.773 at $\mathrm{T}=440^{\circ} \mathrm{C}$ in electrolyte $(\mathrm{A})$. The value of $i_{0}$, which is to be regarded as only a rough estimate, is somewhat lower than typical values (about $1 \mathrm{~A} \mathrm{~cm}^{-2}$ ) expected for exchange current densities of metal dissolutions in molten salts; ${ }^{18}$ nevertheless, it suggests a considerable degree of reversibility on the nickel substrate. The association of a high exchange current density with a strong tendency toward dendrite formation is in agreement with general observations ${ }^{10}$ and theoretical predictions ${ }^{20}$ by Landau and Shyu.

\section{B. Application of Pulsed Potential}

Electrodeposition under the influence of periodically pulsed potentials was also of interest, in view of the well-known usefulness of pulse plating as a means of avoiding dendrite formation. 21 The results are typified by Fig. 4 , in which both the applied potential signal and the current response are shown.

In a typical experiment using the small disk working electrode (area of $0.178 \mathrm{~cm}^{2}$ ), the pulsed potential signal was applied for $20 \mathrm{~min}$, during which the charge accumulation was measured continuously, and the currents developed in the plating pulse and rest period were measured with an oscilloscope at intervals of $5 \mathrm{~min}$. The extent of dendrite formation was assessed by measurement of the length, $d$ (in $\mathrm{mm}$ ), of the largest dendrite present, and the average current density was calculated from the total charge accumulated during the experiment. Measurement of the current pulses provided an additional method of identifying appreciable dendrite formation, since, under potential control, the resulting increase in the surface area of the electrode manifests itself in an increase in the current. The formation of dendrites was associated with the observation of a change in current of about $10 \%$ over 20 min.

The pulsed potential signal used in these experiments involved application of a plating potential $V_{2}$ for time $\tau$, followed by a potential $V_{1}$ for time $r \tau$, where $r>1$. Each of these parameters was found to exert an influence on the formation of dendrites. These influences for electrodeposition from electrolyte (A) vere determined in a two-level factorially designed sequence 

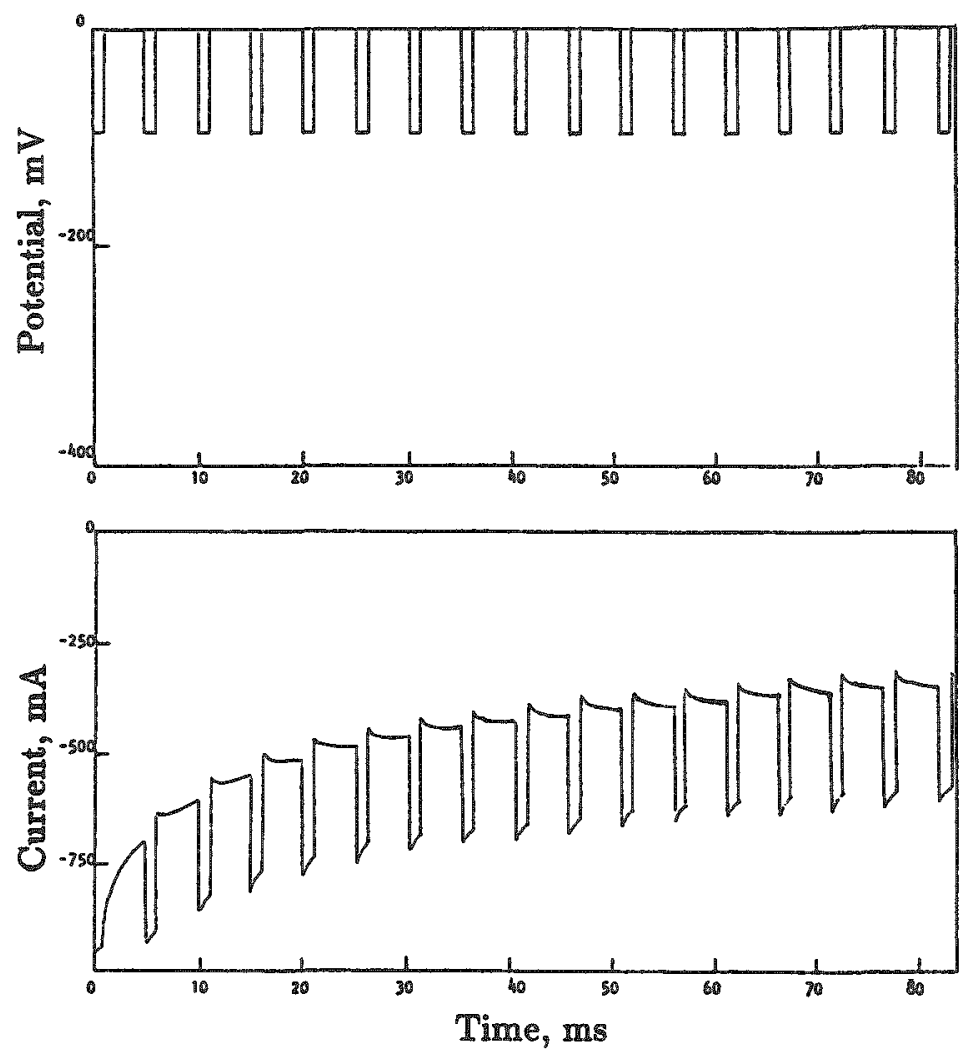

Fig. 4. Pulsed Applied Potential Signal and Transient Current Response of Nickel Test Electrode in Electrolyte (C) at $558^{\circ} \mathrm{C} . \quad\left(\mathrm{V}_{\mathrm{s}}=-100 \mathrm{mV}, \tau=1.0 \mathrm{~ms}\right.$, $r=4.0 ;$ all three symbols are defined in the text)

of experiments in which $V_{1}$ was maintained at $0 \mathrm{mV}$. In this case, the quantity $r$ is equivalent to an off:on time ratio. The independent variables were assigned the following pairs of values, which also define the permissible limits of variation:

Plating potential, $V_{2}$ :

Off:on time ratio, $r$ :

Plating pulse duration, $\tau$ :
$-25 \mathrm{mV}$ and $-250 \mathrm{mV}$

1 and 11

$0.1 \mathrm{~ms}$ and $1.0 \mathrm{~ms}$

The dependent variable was the dendrite length, $d$, defined in the previous paragraph.

Analysis of the data resulted in a linear equation expressing the main effects of each variable:

$$
d=0.339+22.222\left|V_{2}\right|+0.556 \tau-0.2 r
$$


For a specific value of $\tau$, the condition for avoidance of dendrites $(d=0)$ corresponds to a linear relation between $\left|V_{2}\right|$ and $r$. For the experimentally accessible values of $\tau$, viz., $0.1,0.2,0.5$, and $1.0 \mathrm{~ms}$, these linear relations are graphed in Fig. 5. As $\left|V_{2}\right|$ increases, the plating current increases, but larger values of $r$ are required. These two variables thus exert opposing influences on the overall current density attainable with this technique. Coulometric measurement of the plating yield over 20 min, with values of $\mathrm{I}$ and $\left|\mathrm{V}_{2}\right|$ selected according to $\mathrm{Fig}$. 5, shows that the plating potential exerts the dominant effect. In other words, the gain in overall deposition rate resulting from the use of a larger cathodic overvoltage $\left|\mathrm{V}_{2}\right|$ offsets the loss resulting from the requirement of larger $r$ values for avoidance of dendrite formation.

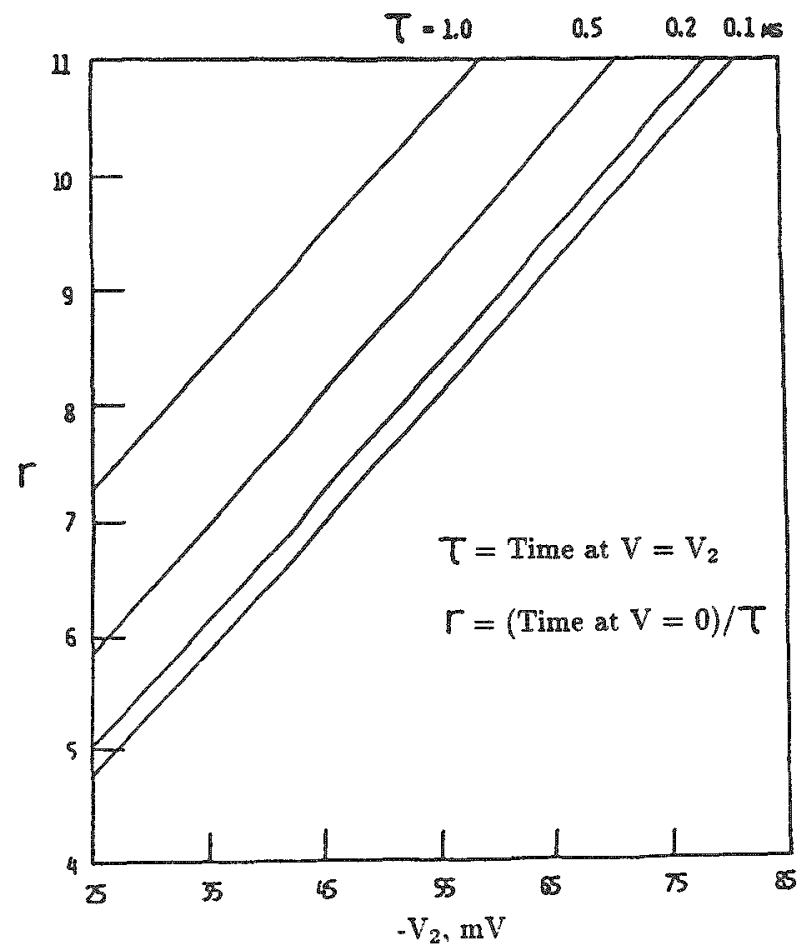

Fig. 5.

Predicted Relation between Potential-Pulse Plating Parameters Corresponding to the Absence of Dendrites

A disadvantage of the approach used in this early work is that it implies an assumption concerning the effects exerted by each independent variable. In other words, the linear relations between $r$ and $\left|V_{2}\right|$ are artifacts of the twolevel experimental design, representing only a crude approximation to the actual situation. In the work on electrolytes (B) and (C), it was decided to avoid this assumption of linearity and to determine the desired relation between $r$ and $V_{2}$ for a constant value of $\tau$ (1 ms) by application of the same experimental technique. If the conditions of each experiment are again represented as points with coordinates $r$ and $V_{2}$, the corresponding values of the dendrite parameter $d$ may be considered to define a surface above the $r-V_{2}$ plane. From such a representation of the data, it is possible to determine the boundary of the "dendrite-free" region in this plane.

The results of this procedure are shown in Fig. 6 for electrolytes (B) and (C) at several temperatures. The largest dendrite-free region was 


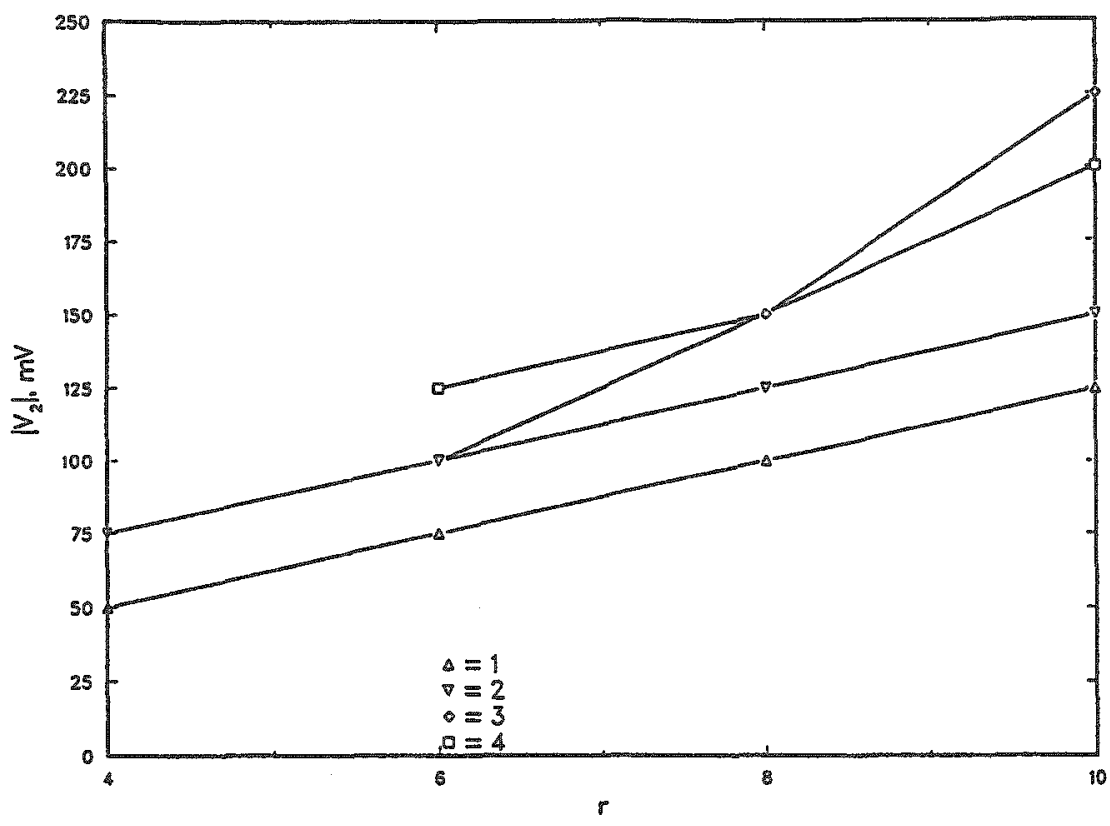

Fig. 6. Boundaries of Dendrite-Free $V_{2}-r$ Regions for Ilectrolyte (B) at $509^{\circ} \mathrm{C}$ (curve 1), Electrolyte (C) at $455^{\circ} \mathrm{C}$ (curve 2), Electrolyte (C) at $504^{\circ} \mathrm{C}$ (curve 3 ), and Electrolyte (C) at $550^{\circ} \mathrm{C}$ (curve 4 ). Regions below the curves are dendrite ixee; above the curves, dendrites form.

observed in electrolyte (C) at $504^{\circ} \mathrm{C}$ (curve 3) and the smallest in electrolyte (B) at $509^{\circ} \mathrm{C}$ (curve 1). Comparison of curves 2 and 3 shows that elevation of the temperature from $455^{\circ} \mathrm{C}$ to $504^{\circ} \mathrm{C}$ results in an enlargement of the range of accessible values of $r$ and $\mathrm{V}_{2}$. Further increase of the temperature, to $550^{\circ} \mathrm{C}$, has only a slight effect on the maximum allowable deposition potential, as shown by comparison of curves 3 and 4 .

In general, the formation of dendrites in metal electrodeposition reflects the extent to which the natural surface irregularities of the substrate are amplified. This tendency is, in turn, determined by a balance of curvature and surface tension effects on the free energy of the deposit, and the effect of concentration polarization produced by the reaction in the vicinity of the surface. 15 The concentration polarization tends to promote growth of dendrites, while the surface free energy associated with small radii of curvature tends to suppress it. For intrinsically fast reactions such as metal dissolution and deposition in molten salts, concentration polarization is particularly pronounced. Thus, in the experiments described above, the off:on time ratio $(r)$ most probably exerts its influence by determining the time available for the relaxation of a locally nonuniform concentration profile.

A more specific conclusion that may be drawn from these results is that the mixed chloride-fluoride electrolyte (C) provides a wider range of accessible operating conditions under the type of pulsed-potential control used 
here. To interpret this result in terms of the differences in composition between electrolytes (B) and (C), it would be necessary to conduct an additional series of experiments in which the concentration effects of each electrolyte component, in turn, were determined. In molten salt systems, a difficulty that arises with studies of this kind is that the range of concentration changes that can be examined is limited by the dependence of the liquidus temperature on composition. However, in connection with the possible effect of fluoride on the tendency toward dendrite formation, Broc ${ }^{12}$ reported that dendrite-free coatings of uranium could be deposited from a11-fluoride melts under rigorously anhydrous conditions.

\section{Coulombic Efficiency}

The coulombic efficiency of uranium electrodeposition from electrolyte (B) was also determined during the series of potential-pulse experiments just described. This was achieved by measurement of the charge recovered by anodization of the electrodeposited uranium at a potential of $400 \mathrm{mV}$ (after examination to determine the dendrite length d). The coulombic efficiency of the electrodeposition process was then computed by expressing this recovered charge as a percentage of the total cathodic charge consumed in the course of the plating experiment.

The coulombic efficiency thus defined is represented as a function of $r$ and $V_{2}$ (as was done above for the dendrite parameter, d) in Fig. 7 . Inclusion of the boundary of the dendrite-free region pertinent to this electrolyte shows that the formation of dendrites is correlated with the observation of coulombic efficiencies significantly less than $50 \%$.

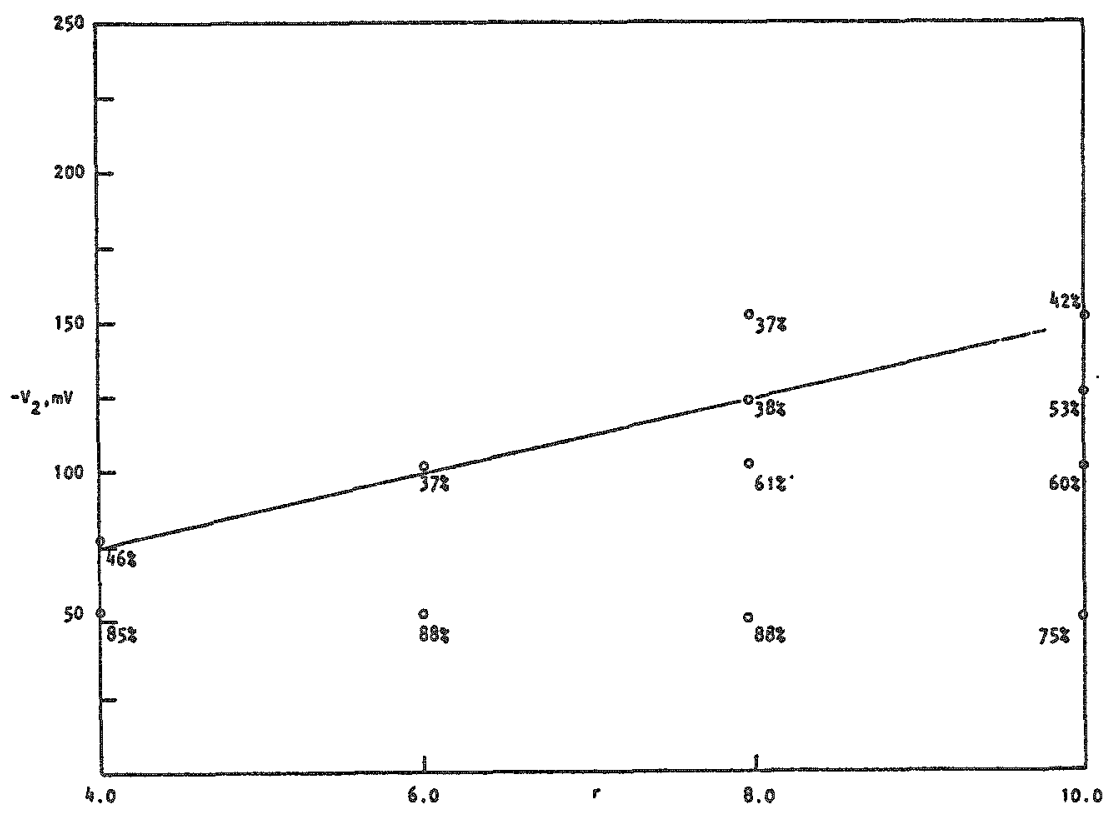

Fig. 7. Coulombic Efficiency for Potential-Pulse Plating as Function of $\mathrm{V}_{2}$ and $\mathrm{r}$ in Electrolyte (B) at $509^{\circ} \mathrm{C}$. Numbers next to data indicate coulombic efficiency. Curve defines the boundary of the dendrite-free region. 
The discrepancy between the consumed and recovered charges in these plating experiments indicates the presence of a parasitic electrode reaction, which becomes progressively more important as the cathodic overvoltage reaches more negative values. This is in agreement with results obtained by Niedrach and Glamm, 4 wo observed a decrease in current efficiency with increasing current under galvanostatic conditions. The explanation proposed by these authors was that the parasitic reaction is the reduction of $\mathrm{UCl}_{4}$ to $\mathrm{UCl}_{3}$ at the cathode. In view of the high purity of the electrolyte starting materials and the glovebox atmosphere used in our work, this indeed seems the most reasonable explanation. The application of a cathodic overvoltage to the working electrode requires the occurrence of an anodic process at the counter electrode, namely, the dissolution of uranium into the molten salt. As the cathodic polarization of the working electrode increases, the resulting increase in the anodic polarization of the counter electrode could result in the further oxidation of $\mathrm{UCl}_{3}$ to $\mathrm{UCl}_{4}$. Diffusion of this $\mathrm{UCl}_{4}$ through the electrolyte, followed by its reduction to $\mathrm{UCl}_{3}$ at the working electrode, would consume some of the charge that would otherwise result in the deposition of uranium.

Interpretation of the observed correlation between dendrite formation and low coulombic efficiency would require a detailed study of the electrode kinetics of uranium in molten chlorides, which was beyond the scope of the present investigation. An additional complication peculiar to this system is that $\mathrm{U}, \mathrm{UCl}_{3}$, and $\mathrm{UCl}_{4}$ can be interconverted by the reverse disproportionation reaction (3), as well as by electrode processes. Although $\mathrm{UCl}_{3}$ is the thermodynamically preferred species, ${ }^{4}$ an assessment of the role of $\mathrm{UCl}_{4}$ in electrodeposition would require knowledge of the rate of this non-electrochemical reaction, in addition to the kinetic parameters of the $\mathrm{U}^{\mathrm{U}} \mathrm{U}^{3+}$ and $\mathrm{U}^{3+} / \mathrm{U}^{4+}$ electrode reactions.

It is interesting that the coulombic efficiency with electrolyte (A) and (C), while not carefully studied, was much higher than that with electrolyte (B). In the cursory studies that were conducted in these two electrolytes, the efficiencies appeared to be in the 80 to $100 \%$ range. Why the efficiency is so much better in these systems is not completely understood, but it is probably associated with the lower concentrations of $\mathrm{U}^{3+}$ in the respective electrolyte systems.

\section{Potential-Pulse Plating Experiments with Large Coupons}

The results of the above investigations were applied to long-time-scale plating experiments with $5 / 8$ in. $(1.6 \mathrm{~cm})$ dia cylindrical nickel, copper, tantalum, and aluminum cathodes, $7.74 \mathrm{~cm}^{2}$ in area. The bottom circular faces of these coupons were polished with diamond paste to a $1 \mu \mathrm{m}$ finish. In the first experiments, coupons were also etched to remove oxide films and expose crystal faces so that epitaxial growth of the electrodeposit would be enhanced. The etchant used was either a mixture of nitric acid, acetic acid, and water (for nickel and copper) or concentrated sulfuric acid (for tantalum). Since this etching step did not exert an appreciable effect on the resulting coating, it was subsequently discontinued. The same effects were achieved instead by anodic dissolution, to be discussed below. 
Pulse-plating parameters, selected from Fig. 5, were $\tau=0.1 \mathrm{~ms}, \mathrm{~V}_{2}=$ $-75 \mathrm{mV}$, and $r=10.3$, and the average current density achieved with this technique was between 3 and $5 \mathrm{~mA} \mathrm{~cm}^{-2}$. Plating times were usually $21 \mathrm{~h}$, corresponding to an average deposit thickness of approximately 5 mil (130 $\mu \mathrm{m})$.

On the nickel and tantalum coupons, the deposits were in all cases dendrite free and well bonded to the substrate. An example of uranium plated onto nickel is shown in Fig. 8. The uniformity of the deposit increased markedly when a nucleation pulse (current density $-706 \mathrm{~mA} \mathrm{~cm}^{-2}$ for $2 \mathrm{~s}$ ) was applied before commencement of the potential signal. The deposits on copper coupons were also dendrite free but tended to become less uniform when a nucleation pulse was applied.

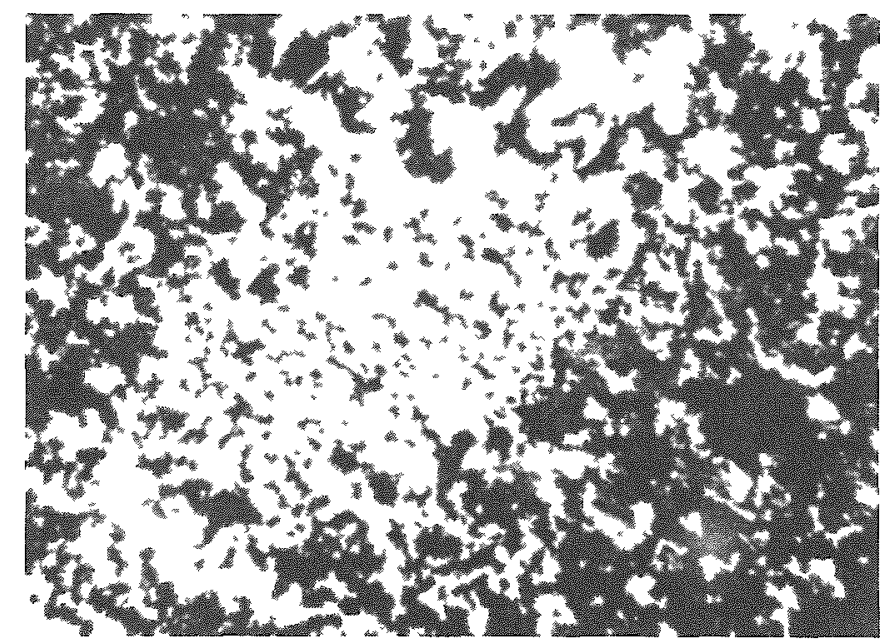

Fig. 8. Potential-Pulse Plated Uranium Deposit on Nickel Coupon (5/8 in. dia) in Electrolyte (A) at $450^{\circ} \mathrm{C}$. Preanodization: 5 coulombs passed at $1.35 \mathrm{~V}$. Nucleation pulse: $-706 \mathrm{~mA} \mathrm{~cm}^{-2}$ for $2 \mathrm{~s}$.

In some experiments, anodization of the coupons was carried out immediately prior to imposition of the nucleation pulse. For nickel and tantalum substrates, this resulted in a slight improvement of the deposit uniformity and a significant improvement in the adhesion of the crystals. In the case of nickel, this latter effect is probably due to the deposition of a uraniumnickel alloy during the nucleation pulse and in the early stages of pulse plating. In principle, an improvement in adhesion could also result from interdiffusion of nickel and uranium. This interdiffusion has been studied by Lebedev et al. ${ }^{22}$ by means of chronopotentiometric measurements on a uraniumplated nickel electrode in a molten $\mathrm{KCl}-\mathrm{NaCl}_{2} \mathrm{UCl}_{3}$ mixture at temperatures between $800^{\circ} \mathrm{C}$ and $900^{\circ} \mathrm{C}$. Considering that the time required for formation of $\mathrm{UNi}_{5}$ by interdiffusion at $800^{\circ} \mathrm{C}$ was observed by these authors to be about $8 \mathrm{~h}$, it is unlikely that interdiffusion would occur to an appreciable extent at the temperature of our experiments $\left(450^{\circ} \mathrm{C}\right)$. A similar explanation probably applies to the tantalum coupons, but in this case the uranium-tantalum system forms a continuous range of solid solutions, ${ }^{23}$ and kinetic data for interdiffusion do not appear to be available. 
The adhesion of electrodeposited uranium to copper coupons was not significantly improved by anodic pretreatment.

In the case of aluminum coupons, alloy formation was observed. The alloy coating was quite smooth but readily became detached from the substrate; chemical analysis and $\mathrm{X}$-ray powder diffraction identified it as $\mathrm{UAl}_{3}$.

\section{E. Current-Pulse Plating Experiments with Large Coupons}

The potential-pulse technique described in the preceding sections was the most convenient technique for screening current-pulse plating parameters for dendrite formation. To obtain a closer correspondence between our work and the procedures usually used in industrial electroplating, we carried out a series of experiments under controlled-current conditions. Of particular interest to us was the application of current-pulse techniques, which are known, in some cases, to provide electrodeposited coatings of finer grain size and superior coherence.21

A bipolar current-pulse technique was applied by Cohen ${ }^{24}$ to the electrodeposition of niobium from molten fluorides. This involves alternate application of cathodic current density $i_{c}$ for time $t_{c}$ and anodic current density $i_{a}$ for time $t_{a}$, which results in the removal of a fraction of the material deposited during each cathodic pulse. The reciprocal of this fraction is given by

$$
q=i_{e} t_{c} / i_{a} t_{a}
$$

In terms of $q_{\text {, the ratio of }}$ pulse lengths $\mathbb{R}=t_{c} / t_{m}$, and the time-average current density $\langle i\rangle$, the values of $i_{a}$ and $i_{c}$ are given by

$$
\begin{gathered}
\dot{i}_{a}=\langle i\rangle(1+R) /(1+q) \\
i_{c}=i_{2} q / R
\end{gathered}
$$

In these equations, the cathodic and anodic currents retain their signs (negative and positive, respectively) so that $q$ is a negative quantity. In this respect our notation differs somewhat from that of Cohen, ${ }^{2}$ who characterized his experiments in terms of the absolute value of this pulse charge ratio.

Experiments with this technique were performed with electrolyte (B) and cylindrical nickel coupons (area of $7.74 \mathrm{~cm}^{2}$ ). The bipolar pulsed currents were preceded by a nucleation pulse, involving application of about $-1 \mathbb{A} \mathrm{cm}^{-2}$ for $2 \mathrm{~s}$, which was intended to ensure uniform coverage of the substrate with crystal nuclei. The coupon shown in Fig. 9 was plated with $i_{c}=-74.9 \mathrm{~mA}$ $\mathrm{cm}^{-2}, t_{c}=4.17 \mathrm{~ms}, i_{a}=107.0 \mathrm{~mA} \mathrm{~cm}-2$, and $t_{a}=2.08 \mathrm{~ms}$, for which $R=2$, 〈i $=-14.3 \mathrm{~mA} \mathrm{~cm} \mathrm{~cm}^{-2}$, and $q=-1.400$. The values of $i_{c}$ and $t_{c}$ correspond to the 


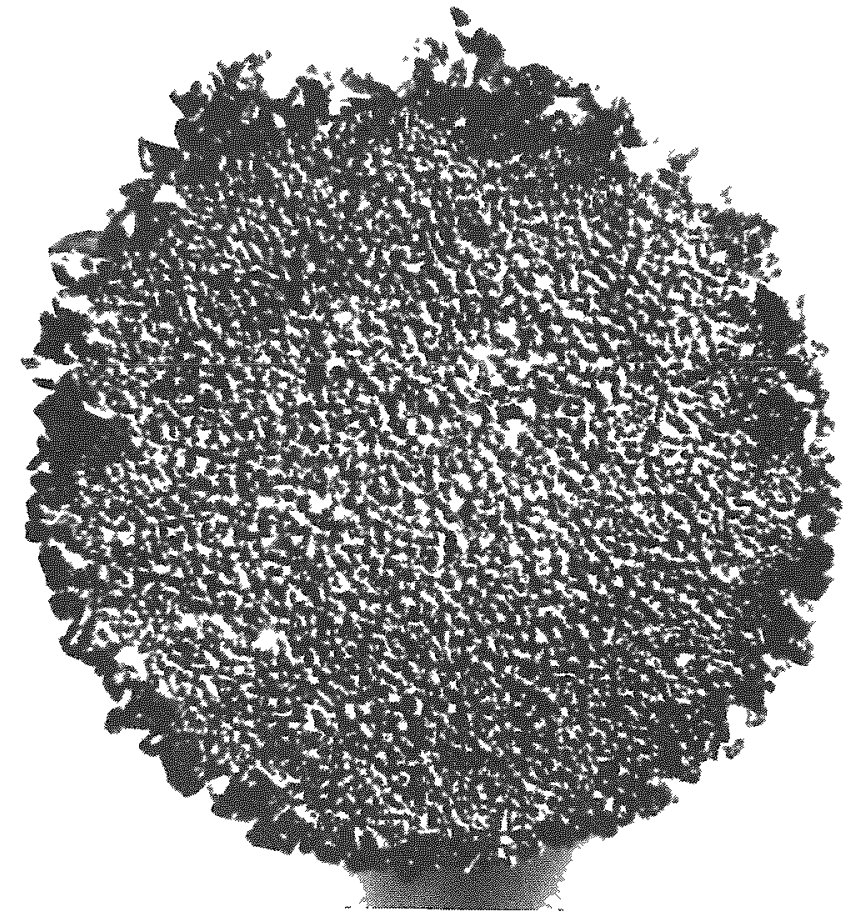

Fig. 9.

Bipolar Current-Pulse Plated Uranium Deposit on Nickel Coupon $(5 / 8$ in. dia) in Electrolyte in) at $504^{\circ} \mathrm{C} . \mathrm{R}=2,\langle i\rangle=-14.3$ $\mathrm{mA} / \mathrm{cm}^{2}, \mathrm{q}=-1.4, \mathrm{t}_{\mathrm{c}}=4.17 \mathrm{~ms}$.

deposition of about a monolayer of uranium per plating pulse, of which $1 / 1.4 \times 100=71.4 \%$ is removed in the following dissolution pulse. Plating time in this case was about $8 \mathrm{~h}$, so that the average thickness was about 7 mil $(180 \mu \mathrm{m})$.

In general, the coherence and uniformity of the deposits were found to be improved by values of $q$ approaching -1 . This is similar to the conclusion reached by Cohen ${ }^{24}$ from his experiments on electrodeposition of niobium from fluoride melts. From Eqs. 7 and 8, it is clear that, for such values of $q$, large pulse current densities are required. Large current densities in the plating pulse can offset the beneficial effects of $q$ being close to -1 , unless the plating pulse length is adjusted so that the amount deposited in each pulse is small. In a series of experiments involving q values progressively approaching -1 and plating pulse lengths adjusted to correspond to the deposition of a monolayer, the quality of the coating was observed to be approximately constant.

\section{F. Tubular Cathode Plating Experiment}

The plating conditions of the coupon shown in Fig. 9 were applied to the $101-\mathrm{cm}^{2}$ tubular cathode in electrolyte (B). A nucleation pulse was not used in this case because the large currents required (about $100 \mathrm{~A}$ ) exceeded the DC output capacity of the power supply. The net charge consumed in the experiment was about $10 \mathrm{Ah}$, corresponding to a nominal coating thickness of 6 mil $(150 \mu \mathrm{m})$. (Uranium electrodeposition requires about one ampere-minute per square centimeter per mil.) After plating, the cathode was halved longitudinally, rinsed with deionized water, dried with methanol, and photographed (Fig. 10). 

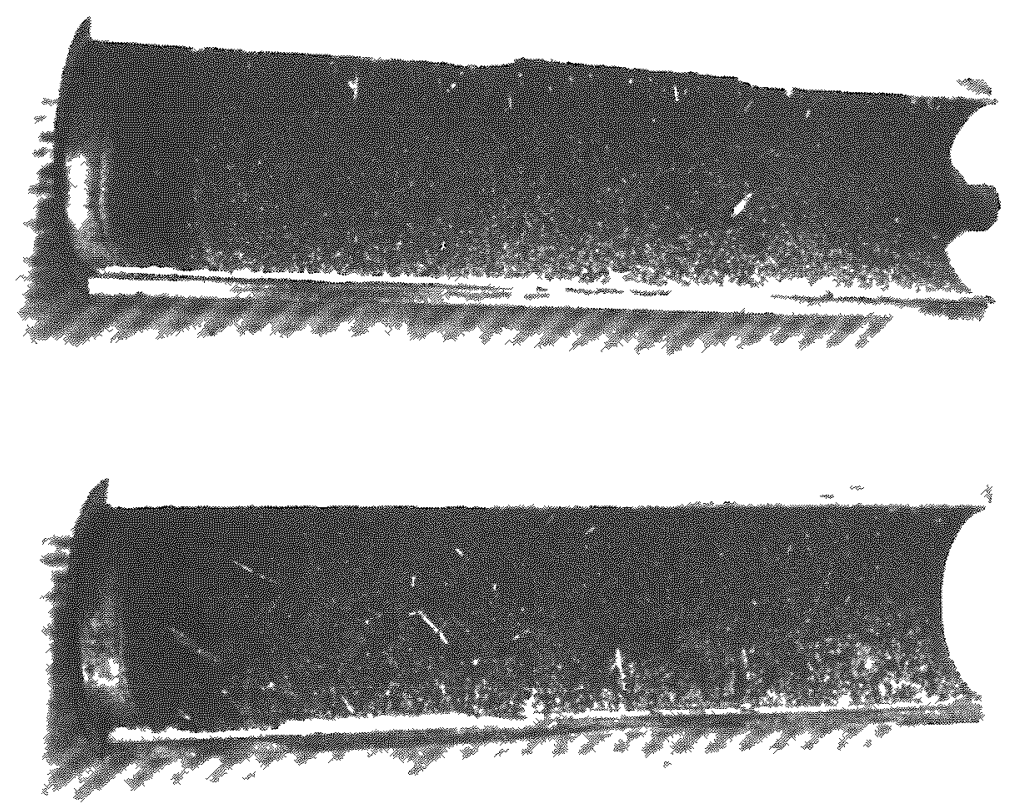

Fig. 10. Bipolar Current-Pulse Plated Uranium Deposit on Nickel Tubular Cathode. Conditions as for Fig. 9.

With the exception of some dendrites, the quality of the deposit on the nickel tubular cathode was as good as, or slightly better than, that obtained with the small coupons. Although our earlier experiments indicated that nucleation pulses tend to improve the uniformity of deposition, their omission in this experiment did not seem to exert much effect. Differences in the anode-cathode separation $[1 / 8$ in. $(0.3 \mathrm{~cm})$ and $11 / 32$ in. $(0.9 \mathrm{~cm})$, respectively] and in the current distribution were probably more important. Another potentially important factor is the surface preparation. The inner surface of the tube was used as-received, with no further mechanical or chemical pretreatment except degreasing with acetone, while the smaller coupons were polished to a $1 \mu \mathrm{m}$ surface finish.

The fact that the dendrites are concentrated on the side opposite the current collector suggests that the temperature distribution in the cell could have been nonuniform. Heat conduction along the heavy-walled currentcollector tube could have caused a temperature gradient, resulting in electrolyte convection, uranium concentration gradients, and thermogalvanic effects. Such a nonuniform temperature distribution would have been compounded by the radiative, rather than conductive, heating of the crucible in the furnace well. 


\section{CONCLUSIONS}

In this report, it is shown that a potential-pulse plating technique, involving deposition pulses separated by zero-potential rest periods, can be used to produce dendrite-free deposits of uranium on various substrates. A technique for determining the optimal plating conditions is described, and it is shown using this technique that the widest range of accessible operating conditions is found in the molten chloride-fluoride electrolyte (C) at $504^{\circ} \mathrm{C}$. In experiments on large coupons, positive effects of preanodization and nucleation pulses on the adhesion and uniformity of deposits have been observed. Our best results, hovever, have been obtained with a bipolar current-pulse technique involving alternate deposition and dissolution pulses. 0verall current densities of about $14 \mathrm{~mA} \mathrm{~cm}^{-2}$ have been achieved, and the application of this technique to a large tubular cathode has been demonstrated.

If future work is to be carried out on this project, we recomend that it be done with an all-fluoride ion electrolyte and the bipolar current-pulse technique.

\section{ACENOWLEDGMENS}

This work was conducted for the U.S. Department of Energy under contract Nos. W-31-109-Eng-38 and DE-AC05-840R21400. The authors are grateful to Drs. J. Bullock and K. M. Myles for their support and to Mr. Z. Tomezuk for helpful comments. Preliminary discussions with Dr. R. Varma are also acknowledged. 


\section{REFERENCES}

1. F. H. Driggs and W. C. Lilliendahl, Ind. Eng. Chem. 22, 516 (1930).

2. M. Kolodney, J. Electrochem. Soc. 129, 2438 (1982).

3. C. Marzano and I. Noland, Argonne National Laboratory Report ANL-5102 (1953).

4. I .W. Niedrach and A. C. Glamm, J. Electrochem. Soc. 103, 521 (1956).

5. F. Caligara, L. Martinot, and G. Duyckaerts, Bu11. Soc. Chim. Belges 76, 211 (1967).

6. D. M. Gruen and R. A. Osteryoung, Ann. N.Y. Acad. Sci. 79, 897 (1960).

7. D. Inman, G. J. Hills, L. Young, and J. 0'M. Bockris, Trans. Faraday Soc. 55, 1904 (1959).

8. F. Caligara, L. Martinot, and G. Duyckaerts, Bull. Soc. Chim. Belges 70, $5(1967)$.

9. D. M. Gruen and R. L. MeBeth, J. Inorg. Nuc1. Chem. 2, 290 (1959).

10. F. Caligara, L. Martinot, and G. Duyckaerts, Bu11. Soc. Chim. Belges 76, 26 (1967).

11. D. S. Poa, Z. Tomczuk, and R. K. Steunenberg, J. Electrochem. Soc. 135, 1161 (1988).

12. M. Broc, Etude de Revêtements Métalliques Préparés par Electrolyse Ignée, French Atomic Energy Commission Report CEA-R4291 (1978).

13. G. Wranglèn, Electrochim. Acta 2, 30 (1960).

14. T. A. Witten and L. M. Sander, Phys. Rev. Lett. 47, 400 (1981); Phys. Rev. B29, 5686 (1983).

15. A. R. Despic and K. I. Popov, in B. E. Conway and J. 0'M. Bockris (eds.), Modern Aspects of Electrochemistry, Vol. 7, Plenum Press, New York, p. 199 (1972).

16. V. N. Desyatnik and B. V. Dubinin, J. Appl. Chem. USSR 48, 885 (1975).

17. G. Boisde, G. Chauvin, H. Coriou and J. Hure, Electrochim. Acta 5, 41 (1961).

18. A. D. Graves, G. J. Hills and D. Inman, Adv. Electrochem. Electrochem. Eng. 4, 117 (1966). 
19. U. Landau and J. H. Shyu, EPRI Report EM-2937 (March 1983).

20. J. H. Shyu and U. Landau, Morphological Stability and Dendrite Growth in Electrodeposition, "Extended Abstracts, 166th Meeting of the Electrochemical Society, Los Angeles, CA, October 14-19, 1979, Vol. 79-2, p. 427 (1979).

21. The Canning Handbook of Surface Finishing Technology, 23rd Ed., published by W. Canning in association with $E$. and F. N. Spon Ltd., Birmingham (1982).

22. V. A. Lebedev, V. I. Pyatkov, R. R. Abdrakhmanov, I. F. Nichkov, S. P. Raspopin, and N. V. Nazarov, Zh. Fiz. Khim. 48, 2521 (1974).

23. G. H. Schram, P. Gordon and A. R. Kaufmann, Trans. Meta11. Soc. AIME 188, 195 (1950).

24. U. Cohen, J. Electrochem. Soc. 128, 731 (1981). 
Distribution for ANL-89/26

Internal:

J. P. Ackerman

J. D. Arntzen

J. E. Battles

I. Burris

C. C. Christianson

D. F. Fischer

E. C. Gay

J. E. Harmon

T. R. Johnson

R. F. Malecha
S. L. Marsha11

J. E. Matos (3)

W. E. Miller

T. P. Mulcahey

K. M. Myles

P. A. Nelson

R. D. Pierce

L. Redey

M. J. Steindler

R. $\mathbb{K}$. Steunenberg
Z. Tomezuk

A. Travelli

G. F. Vandegrift (5)

D. R. Vissers (10)

R. D. Wolson

ANL Patent Dept.

ANL Contract File

ANL Library

TIS Files (3)

\section{External:}

DOE-OSTI, for distribution per UC-504 (112)

Manager, Chicago Operations office, DOE

Chemical Technology Division Reviev Committee Members:

S. Baron, Brookhaven National Laboratory, Upton, NY

N. Jarrett, Noel Jarrett Associates, Lower Burre11, PA

L. Newman, Brookhaven National Laboratory, Upton, NY

J. Stringer, Electric Power Research Institute, Palo Alto, CA

J. B. Wagner, Arizona State University, Tempe, AZ

R. G. Wymer, Oak Ridge National Laboratory, Oak Ridge, TN

E. B. Yeager, Case Western Reserve University, Cleveland, OH

J. Bullock, Martin Marietta Energy Systems, Inc., Dak Ridge, TN

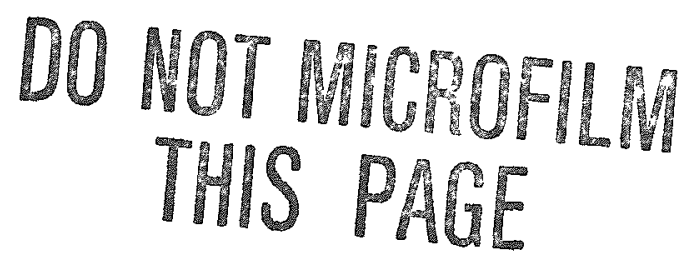

